\title{
Rural Credit and Rural Development: Some Issues
}

\author{
SarfraZ K. Qureshi, Kalbe Abbas, Ahmed NaEem Siddiqui, \\ and EJAZ GHANI*
}

\section{INTRODUCTION}

Credit is an important instrument of acquiring command over the use of working capital, fixed capital and consumption goods. In the wake of Green Revolution, land and labour have receded into the background as predominant factors of growth. Use of capital and adoption of modern techniques of production which have become major sources of growth of agricultural output necessitate access to credit markets for financing their use. Institutional sources of credit have become quite significant during the last few years. The rapid expansion of credit from institutional sources can be seen from various indicators. The total disbursement of agricultural loans has gone up from Rs. 306.75 million in 1972-73 to Rs. 5,102.14 million in 1981-82. On a per acre basis, the loans increased from Rs. 7.33 in $1972-73$ to Rs. 106.83 in $1981-82$. In this perspective, the disparities in income and wealth in rural areas would crucially depend on the distribution of capital among farms of different sizes and occupational groups. Neglecting equitable distribution of credit as a policy instrument for rural income redistribution may be a serious omission by the policy-makers interested in an improvement of rural equity.

It is easy to suggest a link between credit and distribution but difficult to establish the exact relationship between the two variables. Income-distribution effects of the credit delivery may depend on (i) recipients of credit, i.e. the size and type of farm on which credit is used, (ii) the price paid for the borrowed funds, and (iii) productivity of the activities financed by credit. We shall present evidence on each of these aspects to get an idea of the impact of credit on the redistribution of income in rural areas.

*Dr. Qureshi is Chief of Research, Messrs. Abbas and Siddiqui are Staff Economists and Mr. Ghani is Research Assistant at the Pakistan Institute of Development Economics, Islamabad (Pakistan) 
Section II describes the broad features of the credit market and credit relations in rural areas. The reforms in the credit distribution system are the subject matter of Section III. The final section sums up the conclusions and suggests some areas for further policy action.

\section{ACCESS TO THE CREDIT MARKET AND CREDIT RELATIONS: A FACTUAL BACKDROP}

Information about the recipients, cost and use of credit is based on data obtained from a Rural Credit Survey conducted in 1972-73, at which about 100,000 rural households were enumerated. The details of the survey have been presented by Qureshi in [2]. Information on various indices of borrowings and the pattern of its use by different categories of households is presented in Table 1.

The table shows that about 35 percent of rural households had negotiated some form of loan during the survey year. The proportion of households reporting borrowing exhibits significant variation from one occupation to another. This proportion was lowest for non-farm households and highest for tenant households. A slight positive relationship between the size of holdings and the proportion of borrowing households is noticed. The variation in the proportion may be traced to a number of factors operating on both the supply and demand sides of the credit market. The credit supply may be available to a greater extent to occupations with larger incomes and higher levels of wealth since such occupations may be relatively more credit-worthy. The demand for consumption credit may be high for occupations with low incomes while the demand for working and fixed capital may be low for such occupations.

The amount of borrowing per rural family was Rs. 531. The corresponding borrowing was Rs. 650 for cultivator households, Rs. 634 for absentee landlords and Rs. 324 for non-farm households. The borrowing per family is positively correlated with the size of farm. The borrowings per family also increased with an improvement in the status of tenure as owners exhibit a higher level of borrowings than tenant households.

The distribution of credit is also highly unequal. Farm households are 63 percent of rural households but they obtain 77 percent of the rural credit. The share of non-farm households is much lower in credit than their relative share in the number of rural households. Owner, owner-cum-tenant and owner non-operator households appropriate a greater proportion of credit than their proportion of rural households, while all other categories of households get less than what their numbers would indicate.

\section{Sources of Credit}

The duality in rural money markets is often a characteristic feature found in most of the developing countries. It should be interesting to look into the 
differences as regards the sources available for obtaining credit for different categories of households. Information on the percentage distribution of loans obtained from different sources indicates that the non-institutional sources of credit are dominant suppliers of credit for all categories of households and, within the category of cultivator farms, for all sizes of farms. In the case of all rural households, 89 percent of the credit was provided by non-institutional sources. The dependence on such sources was least in the case of absentee landlords and most for tenant households. The dependence on the unorganized credit market was a decreasing function of the size of farms. Farms of less than 5 acres had obtained 99 percent of the credit from non-institutional sources while this proportion was only 71 percent for farms larger than 50 acres.

Within the non-institutional sources of credit, friends and relatives are the most important sources of credit for all categories of households and all sizes of farms. In the case of tenants, land-owners are also an important source. Commission agents and traders are another important source of credit for most categories of households but especially for owner and non-farm households. Professional money-lenders and factories do not figure very prominently for most categories of households.

Of the institutional sources of credit, the Agricultural Development Bank of Pakistan (ADBP) and commercial banks are the most important sources. Commercial banks are especially important in the case of absentee landlords while the ADBP is an important source of credit for land-owner households and for large farms.

\section{Use of Credit}

An examination of the various purposes for which borrowed funds were used shows that consumption expenditure, including non-productive items of expenditure, was the single most important purpose of borrowings as it accounted for 48 percent of the total borrowings for all rural families, 45.6 percent for non-farm families, 42 percent for absentee land-owners, 57 percent for tenants and 47 percent for owner households. In cultivator households, borrowed funds were used to finance 34.42 percent of capital expenditure on farm, 8.59 percent of working capital expenditure on farm and 7.71 percent of non-farm business expenditure. In the case of non-farm households, 46 percent of total borrowings were for non-farm business expenditure. Borrowings for consumption purposes show a negative relationship with the size of farm while borrowings for capital and current expenditures show a positive relationship with the size of farm. Non-farm business expenditure financed through borrowings was also important for owner and owner non-operator households. The most important finding that emerges is that a large proportion of the borrowed funds is used for productive purposes even by the rural poor who include tenants, small farmers and non-farm households.

\section{Cost of Credit}

It is commonly believed that rates of interest in the non-institutional credit market are very high in developing countries and that such rates in the organized credit market are deliberately kept low by the government policy. Table 2 presents data on money rates of interest actually charged by different credit agencies.

The most important finding that emerges is that the rates charged by the noninstitutional agencies, though higher than the rates charged by institutional credit agencies, are not outrageously high. The average rate of interest was 10.13 percent for the combined category of both the institutional and non-institutional loans. The percentages were 8.16 and 15.34 for institutional and non-institutional

Table 2

Distribution of Average Rate of Interest and its Variance by Source of Borrowings

\begin{tabular}{lcc}
\hline Credit Sources & $\begin{array}{c}\text { Mean Interest Rate } \\
\text { (Percent per Annum) }\end{array}$ & $\begin{array}{c}\text { Standard } \\
\text { Deviation }\end{array}$ \\
\hline A. Institutional & & \\
$\quad$ Co-operative Societies & 8.60 & 2.47 \\
Co-operative Banks & 8.68 & 2.28 \\
A.D.B.P. & 7.15 & 1.32 \\
Commercial Banks & 8.87 & 1.40 \\
Taccavi & 6.63 & 3.32 \\
Unclassified & 6.48 & 5.26 \\
$\quad$ Sub-Total: A & 8.16 & 1.82 \\
& & \\
B. Non-Institutional & & 9.72 \\
$\quad$ Friends and Relatives & 9.25 & 12.99 \\
$\quad$ Professional Money-Lenders & 18.53 & 9.35 \\
Land-owners & 10.25 & 11.28 \\
Commission Agents and & & 5.28 \\
$\quad$ Merchants & 13.54 & 11.12 \\
Factories & 8.88 & 11.63 \\
Unclassified & 11.28 & 7.06 \\
$\quad$ Sub-Total: B & 15.34 & \\
\hline All Sources: (A + B) & 10.13 & \\
\hline Source: [2]. & &
\end{tabular}


loans respectively. The highest rates were charged by the professional moneylenders, with the marketing intermediaries, landowners, friends and relatives, and factories following them in this order. It is also interesting to note that almost all non-institutional agencies had charged money rates on some of the loans advanced by them which shows that those of their agents who reported zero rates on their advances were either giving incorrect information or were charging high implicit rates of interest to compensate for the practice of not charging explicitly any rate of interest on loans advanced by them.

In the case of the non-institutional sources of credit, most (more than 95 percent) of the loans were without any interest. Only factories advanced loans without interest to the tune of 70 percent of their advances. Whether any implicit interest was charged or not could not be gleaned from the available evidence. Since the interest rate on the non-institutional credit is higher than the interest rate on the institutional credit and the rural poor borrow largely from the non-institutional sources, the cost of credit and the economic strength of rural borrower are inversely related. The poor not only pay a high rate of interest but are also largely excluded from the institutional credit. Since the cost of institutional credit is relatively low, there is an excess demand for credit in the institutional credit market. The rate of return on borrowed funds is artificially high. The lenders need not concern themselves with the end-use of the credit so long as they are assured of full and timely repayment of the loans. For this reason, the lenders follow a policy of security. based lending. Since lending is linked to the availability of collateral, the access to the institutional credit becomes proportional to the assets owned. Given the skewed distribution of land in the rural areas, it is not surprising that a highly unequal distribution of credit was observed to obtain in rural Pakistan. The high cost of credit and the limited access to the credit market have prevented the rural poor from expanding the base of their production activities.

\section{INSTITUTIONAL CREDIT REFORM}

The analysis of credit market and credit relations in the previous section shows clearly that the rural poor, composed mainly of small farmers and non-farm households, have limited access to the institutional credit. The empirical results show that the larger a farmer is, the more likely he is to benefit from the institutional credit. This situation is a result of the lending policies which link credit availability to "credit-worthiness". The empirical findings on the debtor's losing his land and other assets to professional money-lenders or other commercial non-institutional lenders was not clear-cut as rates of interest were not found to be as high as in other developing countries. Nevertheless it can safely be argued that the institutional credit may have worsened income distribution by providing low-cost capital to large landowners and absentee landlords.
The equity case for ensuring a larger flow of credit to the rural poor needs no argument and flows directly from the policy-maker's greater weight in the social welfare function for the welfare of the poor. The efficiency argument for a redistribution of institutional credit runs parallel to the case for a land reform. To improve the distribution of credit, various policy steps have been taken in Pakistan since the early 1970s. Only a brief description of some of the important policy initiatives and a preliminary evaluation of selected policies adopted in Pakistan are presented.

The 1972 Banking Reforms and the nationalization of commercial banks in 1972 had assigned an important role to the State Bank not only to increase the flow of credit to the agricultural sector but also to redistribute it in favour of small farmers. A scheme for agricultural loans was introduced by the State Bank in December 1972. An Agricultural Credit Advisory Committee was also constituted to estimate credit requirement each year for the agricultural sector. The distinctive features of the innovations are many. Firstly, the institutional agencies were urged to move away from the traditional criterion of credit-worthiness in that the banks could advance loans against expected increased production and against personal sureties. Secondly, quotas are fixed for each bank to encourage their lending in support of agricultural and rural development. The non-observance of these quotas leads to an imposition of penalties in the form of non-interest-bearing deposits with the State Bank. Thirdly, a pass-book system was introduced to expedite the approval of institutional credit against land mortgage. The pass-book is a legal document which contains a complete record of the land owned by a particular farmer. Any institutional lender can grant a loan on the security of land by just recording an entry in the pass-book. Fourthly, quotas of production credit for different sizes of farms are fixed under the Agricultural Purposes Rules, 1973. Under these rules, 70 percent of institutional loans must be advanced to farms of less than 12.5 acres, 20 percent to farms between 12.5 acres and 50 acres, and 10 percent to farms larger than 50 acres. Initially these targets were in respect of small loans. In 1980-81 the entire amount of credit to be provided by commercial banks to the agricultural sector was to be treated as a mandatory target. There is also an element of concession in the rate of interest on agricultural loans relative to commercial and industrial loans. Interest-free production loans to small farms are also granted up to a limit for the purpose of financing the use of seeds, fertilizers and pesticides.

The Agricultural Credit Advisory Committee works out the agricultural credit requirement each year. On the basis of the available data on acreage under each crop in each province and observed input-to-acreage ratios for different crops, total physical input requirements are estimated. Using input prices, input requirement is worked out in value terms. Accounting for farmers' own savings and their access to private credit market, an estimate of the total credit supply from institu-
tional lending agencies is worked out. 
Measuring the impact of credit reforms on rural equity is not easy. Almost all government policies affect the distribution of income. Isolating the impact of channelled official credit from the impact of other policies is an impossible task on both conceptual and empirical grounds. The concern with an improvement in the welfare of the small farmers through increased flow of channelled credit is evident from the fixation of quotas and the provision of interest-free loans even to small farms. The introduction of commercial banks in the agricultural lending has proved to be quite effective. The loans from banks have increased sharply. The introduction of supervised credit schemes by some of the credit institutions has also been a positive policy development.

A recent study by National Fertilizer Corporation [1] relating to the production loans by commercial banks shows that smaller farmers do not benefit much from such loans.

The distribution of credit by farm size according to both bank records and Farmers' Survey diverges drastically from the prescribed pattern of distribution. Farmers owning less than 12.5 acres, who should receive at least 70 percent of the total credit, get only 61 percent according to bank records and 48 percent according to the Farmers' Survey data. Farms ranging in area from 12.5 acres to 50 acres get more than their prescribed share according to both the sources of data while farms of more than 50 acres get less according to the bank data and more according to the Farmers' Survey data. Proxy loaning was quite extensive as the bank records showed borrowers who were not traceable on the address shown in the banks' ledgers. Incentives for proxy loaning are provided by interest-free loans to small farmers. Influential borrowers seem to be the real beneficiary of such policies. It is clear that no effective institutional monitoring set-up has been evolved to supervise an effective enforcing of the credit reforms.

Though the pass-book system was introduced in August 1973, yet by 1982 only a small minority of farmers had obtained the pass-books. The proportion of small farmers obtaining such documents was only 29 percent while 91 percent of the farmers owning more than 50 acres had obtained the pass-books. The official cost for obtaining the pass-book was only Rs. 6 per pass-book. The unofficial cost of Rs. 205 per pass-book is quite high. The high cost plus bureaucratic hurdles have perhaps denied the small farmers the advantage of the pass-book system.

There is also a contradiction between a credit reform which is small-farmeroriented and the lending practices of credit institutions which concentrate on loans for lumpy investments. The Agricultural Development Bank provides credit mainly for purchase of tractors, installation of tubewells and special projects. The small subsistence farmers are unlikely to invest in lumpy investments. This contradiction in the lending behaviour indicates clearly the gap between intentions and practices.

\section{CONCLUSIONS AND POLICY IMPLICATIONS}

The foregoing discussion of the structure of rural credit market and the institutional credit reforms needs no elaborate summary. Only broad conclusions and their policy implications need to be highlighted.

Firstly, the dominant role that the non-institutional sources of credit play for the rural poor is quite clearly borne out. Information about the hidden interest rates was not available. The interest rate on the non-institutional credit is much higher than the interest rate on the institutional credit. One implication of this pattern of credit distribution is that the cost of credit is inversely related to the economic strength of the rural borrowers. A proper accounting of the hidden and implicit costs would strengthen this conclusion.

Secondly, the price paid for institutional credit in Pakistan has been kept low by the government. Maintaining low real rates of interest has adverse consequences for income distribution. Low interest rates always imply an excess demand for loans and require lenders to ration the credit not on the basis of productivity of credit but on considerations of credit-worthiness. The rural poor, comprising small landowners, tenants and non-farm households, had very little collaterals of the kind acceptable to the institutional lenders. The low real rate of interest results in an institutional bias in favour of large land-owners, absentee landlords and rich traders in the rural areas. The use of credit by such groups to finance new capital-intensive technologies diminishes the demand for labour and worsens the pattern of income distribution.

Thirdly, the approach adopted by the Agricultural Credit Advisory Committee in estimating the credit needs is incomplete for policy purposes. It estimates the demand for credit on the basis of historically observed cropping pattern and input use. There is a need to take into account the credit requirements arising from the adoption of new technologies. In this regard, the need for further research is quite urgent.

Fourthly, the institutional agencies need an encouragement to move away from their preference of mortgage security for agricultural loans. No hard evidence on the default rates by farm size is available in Pakistan. The informed guess is that default is more common with the influential large farmers who have been most reluctant to repay loans and most able to resist government pressures to repay loans. Some of the commercial banks have started supervised credit schemes. A careful review of such efforts should suggest the most effective way of extending loans to the rural poor on a large scale.

Fifthly, the institutional credit reform of the kind implemented in Pakistan has not been effective, primarily because of the existing unequal distribution of land and the outmoded tenurial set-up. 
Sixthly, the provision of credit may help the poor only temporarily. Lasting improvement cannot be expected unless production relations are equitably restructured. The experience of the pass-book system and of credit quotas for the small farmer in Pakistan clearly indicates the need for a land reform prior to the credit reform. Large land-owners expropriate a large share of cheap institutional credit despite any legislative or executive provision to the contrary. Inequitable working of the economic and social institutions is a major factor explaining limited benefits for the poor. Leakage of credit earmarked for the rural poor is a serious problem. Separate special institutions for lending only to the target group may be established.

Seventhly, the success of any credit programme is contingent upon a favourable policy framework and an infrastructural programme for rural areas. For example, if terms of trade are biased against the rural poor, additional credit may not have the desired impact. The importance of social and eonomic infrastructure also needs no highlighting.

Eighthly, the uses for which additional rural credit is provided should be technically sound. The new technology should be provably profitable if credit support for its adoption is asked for.

Lastly, paucity of data on the relevant variables is a problem for carrying out more rigorous analysis. There is a need for research in all aspects of the rural credit as a supportive device for a proper designing of a credit policy for rural development.

\section{REFERENCES}

1. National Fertilizer Corporation of Pakistan Ltd. Agricultural Credit Survey (Commercial Banks - Production Loans). Lahore. September 1983.

2. Qureshi, Sarfraz Khan, et al. "Pakistan Rural Credit Survey: Analytical Report". Islamabad: Pakistan Institute of Development Economics, and Karachi: State Bank of Pakistan. 1984. (To be published) 


\section{Comments on \\ "Rural Credit and Rural Development:}

Some Issues"

I congratulate the authors on presenting a paper on a subject of vital significance to rural development. The authors have succeeded in providing insights into the utilization pattern of credit in the rural society. The paper gives a brief review of the Pass Book Scheme and the 1972 Bank Reforms. These changes were effected to help in the attainment of national goals. For reasons best known to the authors their description of policies does not adequately capture the policy developments since 1973. Besides the Pass Book Scheme, an easy and convenient procedure for advancing credit has recently been introduced. Now a farmer can get loan by simply producing a certificate and a single application form instead of producing a long list of documents. A certificate about the bona fides of the applicant and the land under his cultivation can now be issued by any dependable and responsible person of the village, besides the chairman of the Union Council, Lumbardar, or Zaildar. Secondly, one single form has replaced the nine documents previously required for the purpose of obtaining production and development loans. The Supervised Credit Scheme (SCS), though in operation since the early '70s on a limited scale by the National Bank of Pakistan, has meanwhile been extensively enlarged in its coverage. The Agricultural Development Bank of Pakistan, which alone accounts for 37 percent of total institutional credit, provides as much as 64 percent of its loans under the Supervised Credit Scheme. The State Bank of Pakistan, too, had been directing the banks to patronize the supervised credit scheme. In fact, banks are urged to bring their whole agricultural loaning system under the umbrella of this scheme. Interest-free loans are being given to small farmers having land holdings up to $12 \frac{1}{2}$ acres in the Punjab and the NWFP, 16 acres in Sind and 32 acres in Baluchistan. Sugar and ghee mills too arrange credits for the growers. The main objective of the credit policy is to help the small farmer.

The credit limit of 70 percent for the small farmers, as mentioned by the authors, can not be correctly evaluated with the data of the NFC survey. The NFC survey has certain drawbacks. For instance, it covered only a limited number of 
farmers and confined itself only to the institutional credit flowing from commercial banks.

The major findings which emerge from the paper are that the small farmers do not get the 70-percent share of institutional loans as stipulated by the agricultural rules of 1973. The reasons explaining the failure to obtain the stipulated amount of credit include the linking of credit availability to credit-worthiness, proxy loaning, the cost of pass-book, and bureaucratic hurdles.

Some facts need to be set right before I proceed further. The mandatory limit set for the commercial banks' credit to the small farmer was about 50 percent of the total agricultural credit. According to the NFC's Farmers' Survey, 48 per cent of the total agricultural credit issued by commercial banks was received by the small farmers. Their share stood at 60 percent in the case of the ADBP loans in 1982-83. These facts also show improvement over time.

I must emphasize here that there are certain characteristics of both the large and small farms which must be kept in view. For instance, large farms will get inherently more loans as they are capital-deepening while the small farms are labourintensive and thus have a high propensity to replace capital with labour. It is but natural that their share in the overall credit pie would be disproportionate to their share in total farms. I mean here they will be getting less credit per holding as against the large farms whose capital-cum-labour structure is more heavily tilted towards the former variable; but as far as credit availability per acre is concerned, the small farmer is still favourably placed.

Proxy loaning is nothing but an extension of credit to other landholders. In certain cases, proxy loans may ultimately benefit the medium or small farmers.

The authors have found faults with the credit procedures, suggesting that as far as the issuance of Pass Books was concerned the small farmer was the one who faced difficulty in having access to the book. The fact, however, is that the small farmer was neither in a position of getting the so-called 'desired' credit, nor in need of it. With the introduction of improvement in credit policy, the farmer is now in a position to obtain easily the supervised credit.

Demand for credit is a function of many factors, such as rate of return, financial constraints, level of technology, degree of commercialization of agriculture and stage of development. These independent variables need to be looked into before one could pass any judgement about the fulfilment of the credit requirements of the small farmer. Notwithstanding this fact, incentives in the credit policy significantly contribute to pushing up the demand for credit. The farmer has his own set of opportunity costs and works out the economics which finally determine his decisions. The authors need to undertake quite an extensive exercise based on a much larger data-coverage before they can achieve meaningful results. Despite these limitation of analysis, however, the authors have presented quite a useful scenario of the existing pattern of credit supply. Their study, if used carefully, can surely help in instituting qualitative improvement in the formulation of national credit policy for the rural sector.

Economic Analyst,

Mushtaq Ahmad

Government of Pakistan,

Islamabad 